\title{
The Present Day Situation On Standard Albanian and the Theory of Argumentation about it
}

\author{
Edlira Mantho \\ "EQREM ÇABEJ" UNIVERSITY \\ ALBANIAN LANGUAGE AND LITERATURE DEPARTMENT \\ LAGJJA “18 SHTATORI”, GJIROKASTËR, ALBANIA \\ eda_mantho@yahoo.com
}

\begin{abstract}
The primary goal of this article is to examine the strand that connects Albanians of all regions: the standardization of the Albanian language. The Albanian language, which allows for identification, protection, development and the conception of our union as a nation, is being transformed into an instrument of division, not only separating Albanians into Ghegs and Tosks, but also according to political borders. Recently, an argument in Kosovo has emerged demanding that standard Albanian not be used at all. This argument itself is comprised of several sub-currents distinguished by their specific views on standardization. The various positions are as follows: 1. The standard language must not change. 2 . The standard language must be revised. 3. Two standards must be adopted. 4 . The standard language should be avoided as it is a product of the violence of a communist dictatorship. 5. A new language, with a different name, should be created. We contend that language evolves and the act of selection is up to its speakers, irrespective of what has been predetermined. Changes to the standard language are necessary, but by no means must they impinge upon the systematic character of the standard. The changes must be made when the language itself suggests them and must not result from violence or short-sightedness. Standard Albanian will continue to be the common language of both Albanians and Kosovar Albanians. Furthermore, by sharing a common language and a common linguistic history, Albanians will have a prosperous future.
\end{abstract}

\section{Introduction}

Recently, it has become common for Albanians to debate a variety of issues, often focusing on the contrary point of view. The more one doubts, the perception that he or she is objective, moral and just increases. This recent trend has led to the reemergence of issues, into the academic and media debate, related to historical events, national identity, religion, and the Albanian literary language intertwined with the standard code. 
Edlira Mantho: The Present Day Situation on Standard Albanian and the Theory Of Argumentation about it

\section{The Albanian literary language and the standard language - a brief overview.}

The designation literary language is often used interchangeably with the term standard language, as understood by English speakers. However, there is a difference between the two designations. The first, namely the designation literary language is broader, as it refers to the standard variant of the language, as well as the "language of literature" (Artistic). On the other hand, the standard language refers to the model of how a language is used. It embodies the strict implementation of the totality of norms as well as phonetic, lexical, and grammatical rules of the Albanian language, which are obligatory for all speakers regardless of environment: academic circles, politics, media and elsewhere. This essential distinction has been brought to the fore by Eqrem Çabej when he underlined the fact that with the formation of the Albanian state the Albanian language has developed and will develop further, because a state cannot be imagined without a unified language. But here I am not talking about a single literary language, because the writers can continue to write in their dialects. In terms of literature, I don't see a misfortune in the fact that the Albanians do not all write their language in the same form, but in two different dialectal forms. The greatest flowering of literature in ancient Greece took place in the period of the dialects. ${ }^{1}$

\section{The five currents regarding with standardization of Albanian language.}

What is the current situation regarding the single strand that connects Albanians of all regions: to the standardization of language?

While many civilized nations cultivate and respect their standardized language, (e.g. the English, the French, the Hungarians, the Croatians, etc) as the most essential instrument demonstrating national identity, Albanians, on the contrary, are attacking and denying this standard. The Albanian language, which allows for identification, protection, development and the conception of our union as a nation, is being transformed into an instrument of division, not only separating Albanians into Ghegs and Tosks, but also according to political borders.

It is gernerally accepted that the selection of a dialect as the basis of a standard language has extra linguistic motives. The issue has typically been resolved by selecting the predominant literary variant during the period of national awakening. Scholars who have dealt with the issue of the dialectal basis of the literary Albanian language, from Aleksandër Xhuvani in 1905, to Skënder Riza, Dhimitër Shuteriqi, etc., have underlined some functions that the Tosk dialect has fulfilled from the middle of the 19th century until the present day. A great number of newspapers, compositions, school texts, etc. were written in Tosk. The writers of the National Renaissance also used the Tosk. This precedent led to the dominance of the Tosk

\footnotetext{
${ }^{1}$ Ledi Shamku - Shkreli: Why was the literary language equalized in the standard code? The second injustice had done to the Albanian language, in the daily "Shekulli", 23 February, 2007: 14.
} 
dialect. Under these circumstances, it became necessary for a state linguistic policy to be developed in support of the standard, which led to the codification of standard Albanian for the first time in our history. Thereafter, standard Albanian was made obligatory at schools and implemented in public settings. It is worthwhile to mention here the significant work of the scholars E.Çabej, A. Kostallari, Sh. Demiraj, M.Domi, Xh.Lloshi, J.Thomai, J.Bulo, E.Lafe etc., with respect to many issues which received attention within Albanian linguistics including: the problems of the relations of literary language with the dialects, linguistic convergence, the supporting dialectical basis of literary language, the history of language, and etymology. With respect to the relation between the literary language and dialects, academician Jorgo Bulo emphasizes: it is true that the official language has been created based on Tosk, but with many parts taken from Gheg, especially in the lexical aspect. The decision to create an official language based on Tosk is not the effort of a local vernacular to prevail over another, but simply a scientific choice, which very well could be the other way around, so that Gheg would be the basis of the official language. ${ }^{2}$

The fact that this language is now 40 years old, verifies that the planning and approval which occurred at the two major Albanological Centres (in Tirana and Prishtina), has been successful. During this 40 year period it has served everyone in many spheres of every day life without presenting tangible difficulties: Ghegs and Tosks, common people and intellectuals alike. Likewise, no serious concern has been expressed by these users regarding serious obstacles in communication or translation, despite these being difficult fields involving the adaptation of semantic meanings of words from other languages, conditioned by different contexts. The negligible distinction between the two dialects has been emphasized by the well-known Danish linguist Holger Pedersen, when he stated that: the difference between the two dialects of Albanian language is much smaller than the dialectal differences of many other languages: from the practical point of view the difference between the two dialects of Albanian language does not have any importance(...) ${ }_{3}$ The difficulties that do exist in the communication between Gheg and Tosk speakers (in the phonetic system, but primariliy in the lexical system) are not totally insurmountable, and do not result from wants or defects of the standard. If we extend our view to the Gheg speaking Kosovars, Macedonians, and Montenegrins, these difficulties can be explained by the current political circumstances of Kosova and beyond, and moreover by the inadeqaute Albanian educational system.

Currently, in Kosovo, the argument has emerged demanding that standard Albanian not be used at all, thus aiming to undo "The linguistic counsel of Prishtina" (1968), and also "The Congress of orthography" (1972) and ignoring the conclusion of the conference that "the Albanian people is one and the Albanian literary language must be one, and common". This argument is divided into several sub-currents, each propounding a different position on the issue of standardization, or in the terms of textual linguistics; each current advocates a certain style of speech, namely the persuasive one. The aim of the latter being to persuade people to change their way of

\footnotetext{
2 J. Bulo: The Tower of Babel... or The Gheg of the standard, in the daily "Standard”, 29 March, 2008: 3.

3 A. Poloska: Linguistic interpretations, Skopje, Menora, 2002: 65.
} 


\section{Edlira Mantho: The Present Day Situation on Standard Albanian and the Theory Of Argumentation about it}

perceiving something. 4 The following is a panorama of the theses and counter theses regarding the issue of standardization:

$>\quad$ The standard language must not change.

$>\quad$ The standard language must be revised.

$>\quad$ Two standards must be used.

$>$ The standard language should be avoided as it is a product of the violence of communist dictatorship.

$>$ Another language should be created, whose name would not be Albanian. Let us analyse them:

\subsection{The first current}

The first current maintains that it is not necessary to make any changes to the standard language. The present day literary Albanian functions very well in many fields, including: state, social, religious, and literary activities. I don't think this official language we have should change - says prof. Jorgo Bulo5. The linguist Ilirjan Mërtiri thinks in the same way: the language is established and I don't think that by making a new standard we would improve anything ${ }^{6}$.

\subsection{The second current}

In the second current we can distinguish two sub-currents: There are linguists who think that the time has come to revise the standard Albanian language. These linguists are in favor of changing or modifying things highlighted by daily practice including: the orthography of proper nouns, the issue of binaries: mat/mas; këpus/këput; gatit/gatis, etc, the orthography of some particular words for which practice has had a predilection like: Europë, europian, euro against Evropë, evropian, evro, and the possibility of some conjunctions, prepositions, or adverbial phrases being written together.

The second sub-current are linguists who favor changes of a deeper character, that is changes which are at variance with the fundamental system of the standard, such as the rules governing the use of $\underline{\ddot{\mathbf{e}}}$. A more extensive reduction of the unstressed vowel $\underline{\ddot{e}}$ is often required in different positions of the word, sometimes in conformity with the northern pronunciation of the word while other times in conformity with the more general pronunciation (this is a very intricate issue, which many think would complicate rather than simplify, the writing of Albanian). In addition, the integration of the infinitive form of Gheg into the standard is sought after. It is a well known fact that from the period of the National Renaissance onward, the infinitive form of Gheg has been a fundamental distinguishing element between the two dialects of the Albanian language (me ba and për të bërë). On the other hand, if this integration would occur, in addition to some resulting morphological difficulties (it must be: me shkue, me shkuem, me shkuar?) the respective substitutions for constructions with modal verbs, which are already established in Albanian, would be required. So this

\footnotetext{
4 E. Mantho: A general view of rhetoric and the argumentative text in the Albanian language, in "University Research”, No. 19, GJR, 2008: 25.

5 In the daily "Standard", 29 March, 2008 (at the same place).

${ }^{6}$ At the same place.
} 
means that in parallel with the constructions: duhet të punoj: duhet të punohet: duhet punuar - two others would be added: duhet me punue, duhet me u punue... and furthermore: mund të lexoj: mundem me lexue: mund të lexohet; mundet me u lexue and others. The complication would continue with the analytical forms of the perfect tense (kam punuar - kam punue); with the forms of passive voice (për t'u mbajtur/me u mbajtë) with the participial adjectives (ujë i gazuar - ujë i gazuam; bjeshkët e nëmura/bjeshkët e namuna) and with the verbal nouns të punuarit, të shprehurit. The scholar and publicist Ardian Vehbiu thinks adds: In my opinion, the standard for simply functional reasons cannot admit the infinitive form of Gheg tale quale which is better to stay where it has always been: in the spoken Gheg and in the literary variants of Gheg 7 The academician Jorgo Bulo expresses the same idea: The existence or not of the infinitive does not constitute any problem. Nowadays we don't use the infinitive, but what is the big thing which has been lost, what problems has it caused to us? - he asks rhetorically. If the infinitive would be included, the whole system of Albanian language would collapse, and that is why it is not accepted in the standard, this form which is one of the bases of Gheg. I don't think it is an element without which the Albanian standard language cannot exist. ${ }^{8}$

\subsection{The third current}

The third current supports the thesis of the creation of two standards. Let us examine it:

As a response to this issue it suffices to mention the existence of other nations with a larger population, with a much longer history of a standard language, who have done and are still doing their utmost to maintain one standard (e.g. German language). We raise the question: "Can we request that in school, in parallel with the standard, other standards be learned ( let us suppose the Gheg used in the 6os in Kosovo; or the standard of the arberesh dialect in Italy) as long as the pupils come with an inherent form or learned and "refined" form in the place where they live? The standard language of Albanian, in Kosovo for the most part, languishes from models of syntactic units with influence from the Serbian language from the time when it was the official language, and consequently this "Serbianised" standard competes fiercely with the standard Albanian already established.

\subsection{The fourth current}

The fourth current attacks the standard language on the basis that it has been established during the time of the dictatorship. According to the publicist Agron Tufa the standard language which leans on the Tosk side constitutes an obstacle to all speakers of Gheg. He adds: the standard language is dismissive of and ruins the style of every Gheg writer. Where does the simplicity stand, if we pass to the condensed speech of the language of poetry? To say "menjëherë" or "saora"? To say "vazhdimisht/ gjithnje// gjithmonë" or "prore? - He propounds. 9 In fact the analyses must serve a better understanding, to inform us, and not rigidly accept or reject something. In this context prof. Bulo says: Albanian must absolutely absorb all the

\footnotetext{
7 A. Vehbiu: The mystique with the Gheg fogs the real problem, in the daily "Shekulli", 5 August 2007: 14.

8 At the same place.

9 At the same place.
} 


\section{Edlira Mantho: The Present Day Situation on Standard Albanian and the Theory Of Argumentation about it}

necessary idiosyncracies of a dialect, so we must have a language with open doors, not with broken down doors. On the one hand, there exist misunderstandings among people, precisely because of their local vernaculars and of certain words, which have not been adopted nationally, but have remained as widespread dialectical idiosyncrasies. On the other hand, as many people as possible must have extensive knowledge of the standard language, as this would help prevent potential social unrest in the country.

The other thesis propounded, to create another linguistic identity, that is Kosovar, trying "to switch" identities due to political circumstances and the historical context, is absurd in its essence. Can it be that due to these "particular historical and political conditions under the pressure of the ruthless dictatorship", that this standard must be discarded, and a new standard be established, "with a new and modern spirit"? And this "democratization" is defended by the notion that while making the decision to adopt this standard, the opinion of everyone will be consulted: philosophers, sociologists, journalists, foreign persons who deal with the study of Albanian language...everyone with the exception of the linguists! At the center of this situation is that they do not want to or cannot master standard Albanian that is "so remote from their local vernacular" and "the language of a totalitarian system". According to the linguist Emil Lafe: The viewpoint of some people to start once again from the beginning, because this literary language was established in the time of communism not only is useless but is harmful. It is more or less the same to argue if Tirana must be the Capital of Albania or not? The flag was hoisted in Vlora, but the capital could have been also Elbasani, Durres or Shkodra. But these things are set once and for all and there is no reason to go backward! The leveled literary language is not like a football championship, where everyone wishes that the team of his town win. ${ }^{o o}$ The scholar Idriz Ajeti is also of this opinion, who argues: the literary Tosk was not helped to develop by communist politics in which Tosk speakers prevailed. Its superiority over the written Gheg was the result of the efforts of many scientific and cultural Albanian generations started more than 100 years ago. ${ }^{11}$

\subsection{The fifth current}

The fifth current is represented by other extremists, who have the courage to totally oppose standard Albanian. In the congress of ' 72 the official language was accepted in its current form, also by the Ghegs, some of whom absorbed this form to prevent national disunity. Whereas now this current has included the issue of standardization in the political struggle, it has tried to transform it into a means of achieving linguistic and political domination in order to take the decisive step in obtaining another national identity, as has happened and is happening to the southern Slavic languages. This group claims that a deliberate deviation from the standard exists. It is true that one does, but only in so far as the language develops and changes continuously. Deliberate deviations, (but at the same time unintentional ones) exist and will exist for stylistic reasons, and in particular

\footnotetext{
${ }^{10}$ E. Lafe: Language and writing, in "Albanian Language”, 3, Prishtinë, 2007: 10.

${ }^{11}$ Q. Murati: To I.Ajeti: Leader for the leveling the Albanian language, in "Albanian Language", 2, Prishtinë, 2007: 39 .
} 
communicative circumstances. This is a normal situation found in all languages. But what is disturbing, is the fact that in Kosovo, many books have been published recently - translations into the so-called "Gheg vernacular", which deliberately avoid the use of the standard norm. Impelled by a clear aim, not only political and ideological, but with underlying intentions to partition the country, along regional and local borders. This is why the scholar Seit Mansaku underlines: To condition the scientific thought by a fixed political ideology, to subordinate it to its function, means to lose the scientific freedom and force science to function on an ideological basis. An independent scientific mind, must avoid every partisan ideology. ${ }^{12}$

As a conclusion we think that:

Language evolves and the selection is up to its speakers, because it is the Albanians who determine what will and will not be said, irrespective of what has been predetermined.

Changes to the standard are necessary, but by no means must they impinge upon the systematic character of the standard. The changes must be made each time the language itself suggests them and must not result from violence or short-sightedness, something which has been emphasized also by the scholar Androkli Kostallari a long time ago: Our society itself is interested in discovering the objective laws of evolution of the literary Albanian language as a social phenomenon, to explain their rhythms, but not to change them, to substitute them or to annihiliate these laws of the language in an arbitrary way. The society picks and chooses from the results of the objective linguistic laws those which best adapt to its development and aid in this development, but do not lead to new laws or results mechanically. The national literary norm is after all a consequence of a selection with general social value. ${ }^{13}$

The majority of linguists agree that the standard language must not touch literature, but has to be confined to education (perhaps in parallel with the local vernacular) and to the administrative language of the state.

The arguments and reasonings for updating Gheg and the invalidation of Tosk, are doomed to remain a hobby of their respective proponents. They have more of a quixotic nature and do not take into account the social functions that the standard currently performs. These "ardent" followers of the Albanian language seek to be victors but: In the language there are no losers or victors but there may be victory or loss for the whole nation.14 Therefore, Albanians will know which their path is: standard Albanian will continue to be the common language of Albanians, and the Albanians of Kosovo, by having a common language and linguistic history, Albanians will have a prosperous future. It is our patriotic duty to concern ourselves more with our own language and to repeat in this moment the saying of Faik Konica: Give me a cultivated and beautiful language and I will give you a civilized nation.

\footnotetext{
12 S. Mansaku: Language as a science and not as politics, in the daily "Shqip", 18 February, 2008: 28.

${ }_{13}$ A. Kostallary: On some functional and structural particularities of Albanian language, in: SF, 2, 1970: 23 - 24.

14 Xh. Lloshi: Six questions for prof. Xhefat Lloshi, in “Albanian Language”, 1, Prishtinë, 2007: 15.
} 


\section{Edlira Mantho: The Present Day Situation on Standard Albanian and the Theory Of Argumentation about it}

\section{Bibliography}

Shkreli, L. 2007. Why was the literary language equalized in the standard code? The second injustice had done to the Albanian language. in Shekulli, p. 14.

Bulo, J. 2002. The Tower of Babel...or The Gheg of the standard, in Standard, p. 3.

Poloska, A. 2002. Linguistic interpretations, Skopje, Menora, p. 65.

Mantho, E. 2008. A general view of rhetoric and the argumentative text in the Albanian Language, in: University Research, 19, p. 25.

Vehbiu, A. 2007. The mystique with the Gheg fogs the real problem, in: Shekulli, p.14.

Lafe, E. 2007. Language and writing, in Albanian language, Prishtinë, p.10.

Murati, Q. 2007. To I. Ajeti: Leader for the leveling the Albanian language, in: Albanian Language, 2, Prishtinë, p. 39. 